\title{
ERRATA
}

MUNHOZ, J.S.B. Caracterização da produtividade florestal e dos padrões de crescimento de Pinus taeda L. no sul do Brasil através de análise de tronco. Piracicaba, 2011. 116p. Dissertação (Mestrado em Recursos Florestais) - Escola Superior de Agricultura "Luiz de Queiroz". Universidade de São Paulo

\begin{tabular}{|c|c|c|c|}
\hline Página & Linha & Onde se lê & $\begin{array}{l}\text { Leia-se } \\
\text { instaladas em } 2006 \text { e } 2007\end{array}$ \\
\hline & $\begin{array}{l}9 \\
1 \text { e } 2\end{array}$ & $\begin{array}{l}\text { plantadas em } 2006 \text { e } 2007 \\
\text { totalizando } 48 \text { árvores }\end{array}$ & $\begin{array}{l}\text { Instaladas em } 2006 \text { e } 2007 \\
\text { com excessão das } 9 \text { parcelas }\end{array}$ \\
\hline & & & $\begin{array}{l}\text { em Três Barras, totalizando } 30 \\
\text { árvores }\end{array}$ \\
\hline 75 & 4 & estoque de $132 \mathrm{~m}^{3} \mathrm{ha}^{-1}$ & estoque de $314 \mathrm{~m}^{3} \mathrm{ha}^{-1}$ \\
\hline 75 & 6 & estoque de $314 \mathrm{~m}^{3} \mathrm{ha}^{-1}$ & estoque de $132 \mathrm{~m}^{3} \mathrm{ha}^{-1}$ \\
\hline 91 & 8 & 56 a $131 \mathrm{Mg} \mathrm{ha}^{-1} \mathrm{ano}^{-1}$ & 6.2 a $14.5 \mathrm{Mg} \mathrm{ha}^{-1} \mathrm{ano}^{-1}$ \\
\hline
\end{tabular}

Página 41

Eq. 4: $k=\frac{V c a s c a}{V s}$

\section{Página 42}

Item 3.4.1.2 - As curvas de sítio das parcelas de Três Barras foram determinadas a partir dos dados de altura de quatro árvores dominantes (maior DAP) de cada parcela dos inventários de 2006 a 2010, juntamente com os dados de altura dominante da parcela 13 (parcela com altura mais semelhante às alturas das parcelas de Três Barras). A partir destes dados foi possível determinar uma curva de sítio para as nove parcelas da região de Três Barras. 